\title{
PARAMETER FISIK DAN JUMLAH PERKIRAAN TERDEKAT COLIFORM AIR DANAU BUYAN DESA PANCASARI KECAMATAN SUKASADA BULELENG
}

\author{
${ }^{1}$ N.L.P.M. Widiyanti, ${ }^{2}$ I.W.S. Warpala, ${ }^{3}$ I. A. P. Suryanti \\ Jurusan Pendidikan Biologi \\ Universitas Pendidikan Ganesha \\ Singaraja, Indonesia \\ e-mail : ${ }^{1}$ manikwidiyanti@gmail.com, ${ }^{3}$ dayusuryanti@yahoo.co.id
}

\begin{abstract}
Abstrak
Air merupakan kebutuhan pokok bagi makhluk hidup di bumi ini. Air bersih maupun air minum harus memenuhi syarat fisik, kimia, mikrobiologi dan radioaktif. Parameter mikrobiologi merupakan salah satu parameter yang harus mendapat perhatian karena dampaknya yang berbahaya yaitu dapat menimbulkan penyakit infeksi. Dalam penyediaan air minum harus memenuhi syarat-syarat sesuai dengan Permenkes RI No 492/MENKES/Per/IV/2010. Menurut ketentuan WHO dan APHA, kualitas air ditentukan oleh kehadiran dan jumLah bakteri di dalam air. Terdapat beberapa jenis bakteri yang hidup di dalam air antara lain bakteri coliform dan jenis Escherichia coli sebagai indikator pencemaran air. Coliform merupakan bakteri fekal berasal dari tinja hewan termasuk manusia. Danau Buyan yang terletak di Desa PancasariSukasada-Buleleng- Bali merupakan kawasan pariwisata yang air danaunya digunakan untuk pariwisata air yaitu dayung dan memancing. Jenis penelitian ini adalah penelitian deskriptif. Hasil penelitian menunjukkan parameter fisik air danau Buyan yang terukur pada saat penelitian : pH terendah dan kecerahan tidak memenuhi baku mutu air. Sedangkan parameter $\mathrm{pH}$ tertinggi, salinitas dan suhu memenuhi baku mutu air. JumLah total bakteri coliform pada air danau Buyan berdasarkan metode Most Probable Number berkisar antara $20->1100$.
\end{abstract}

Kata kunci : air, danau Buyan, jumLah perkiraan terdekat coliform, parameter fisik,

\begin{abstract}
Water is a basic requirement for living creatures on the earth. Clean water and drinking water must be having completely requirements of physical, chemical, microbiological and radioactive. Microbiological parameter is one of the parameters that should receive attention because of the impact of harmful that can cause infectious diseases. In the provision of drinking water must meet the requirements in accordance with the regulations of health minister of the Republic of Indonesia Num 492/MENKES/Per/IV/2010. Under the terms of WHO and APHA, water quality is determined by presence and number bacteria in water. There are several types of bacteria that live in the water, according to coliform and Escherichia coli species as an indicator of water pollution. Fecal coliform is bacteria derived from feces of animals including humans. Lake Buyan is located in the village Pancasari-Sukasada-Buleleng-Bali, is a tourist area that lake water is used for water tourism are paddle and fishing. This research was used descriptive for the design. The results of the research showed physical parameters that measured during the study are $\mathrm{pH}$ lows and brightness do not meet water quality standards. While the highest $\mathrm{pH}$, salinity and temperature meets water quality standards. The total number of coliform bacteria in the water of lake Buyan based on MPN methods were range $20->1100$.
\end{abstract}

Key words : water, lake Buyan, most probable number of coliform, physical parameters 


\section{PENDAHULUAN}

Air merupakan kebutuhan pokok bagi makhluk hidup di bumi ini. Air bersih maupun air minum harus memenuhi syarat fisik, kimia, mikrobiologi dan radioaktif. Parameter mikrobiologi merupakan salah satu parameter yang harus mendapat perhatian karena dampaknya yang berbahaya yaitu dapat menimbulkan penyakit infeksi (Athena et. al., 2004; Chandra, 2009). Air mudah tercemar oleh mikroorganisme patogen yang masuk melalui limbah. Penyediaan air minum harus memenuhi syarat-syarat sesuai dengan Peraturan Menteri Kesehatan Republik Indonesia No 492/MENKES/Per/IV/2010..

Berdasarkan Peraturan Gubernur Bali Nomor 8 Tahun 2007 tentang Baku Mutu Lingkungan Hidup dan Kriteria Baku Kerusakan Lingkungan Hidup, keberadaan mikroba pada air menjadi salah satu indikator yang digunakan untuk menentukan mutu air. Menurut ketentuan WHO (World Health Organization) dan APHA (American Public Health Association) saat ini, kualitas air ditentukan oleh kehadiran dan jumLah bakteri didalamnya, terdapat beberapa jenis bakteri yang hidup di dalamn air yaitu bakteri Coliform dan E. coli. Secara mikrobiologis, keberadaan bakteri coliform pada air dapat dijadikan penentu apakah air tersebut layak digunakan untuk keperluan tertentu seperti untuk air minum, perikanan, peternakan, pertanian, dan lain-lain.

Danau Buyan yang terletak di kawasan Desa Pancasari, Kecamatan Sukasada, Kabupaten Buleleng Bali. Kawasan Danau Buyan merupakan kawasan pariwisata dengan tersedianya beberapa villa, tempat rekreasi untuk memancing, dan kawasan perkemahan di tepi Danau Buyan, daerah pemukiman, dan perkebunan. Segala aktifitas yang dilakukan di kawasan Danau Buyan memberikan pengaruh terhadap ekosistem Danau Buyan.
Danau Buyan telah mengalami degradasi kualitas lingkungan yang cukup tinggi. Bagian timur, selatan dan barat daya telah mengalami pendangkalan dan pertumbuhan eceng gondok yang berlebihan. Pendangkalan terjadi terutama karena tingginya tingkat erosi saat musim hujan. Tanah yang berasal dari daerah tangkapan hujan terbawa aliran air menuju danau. Keadaan ini semakin diperburuk oleh kondisi danau karena tidak terdapat aliran air keluar sehingga pencemar akan mengalami akumulasi. Selain itu, pemanfaatan daerah tepi danau dapat menjadi salah satu penyebab pencemaran air danau (Effendi, 2007)

\section{METODE}

\section{a. Jenis Penelitian}

Jenis penelitian ini adalah penelitian deskriptif dengan melakukan survei lapangan.

\section{b. Lokasi Penelitian}

Penelitian dilaksanakan di perairan danau Buyan desa Pancasari kecamatan Sukasada Buleleng untuk mengukur kualitas fisik air danau. Menentukan jumLah SPC dan kualitas air danau Buyan secara Most Probable Number (MPN) dengan uji penduga (presumptive test) yang dilanjutkan uji penegas (confirmed test) dan dengan uji pelengkap (completed test) dilaksanakan di Laboratorium Mikrobiologi Jurusan Pendidikan Biologi FMIPA Universitas Pendidikan Ganesha.

\section{c. Subjek dan Objek}

Subjek penelitian : seluruh perairan di danau Buyan desa Pancasari Sukasada Buleleng. Objek penelitian adalah $250 \mathrm{~mL}$ sampel air Danau Buyan yang diambil di 10 stasiun pengambilan sampel air. Sampel diambil secara duplo di masing-masing stasiun (gambar 1). 


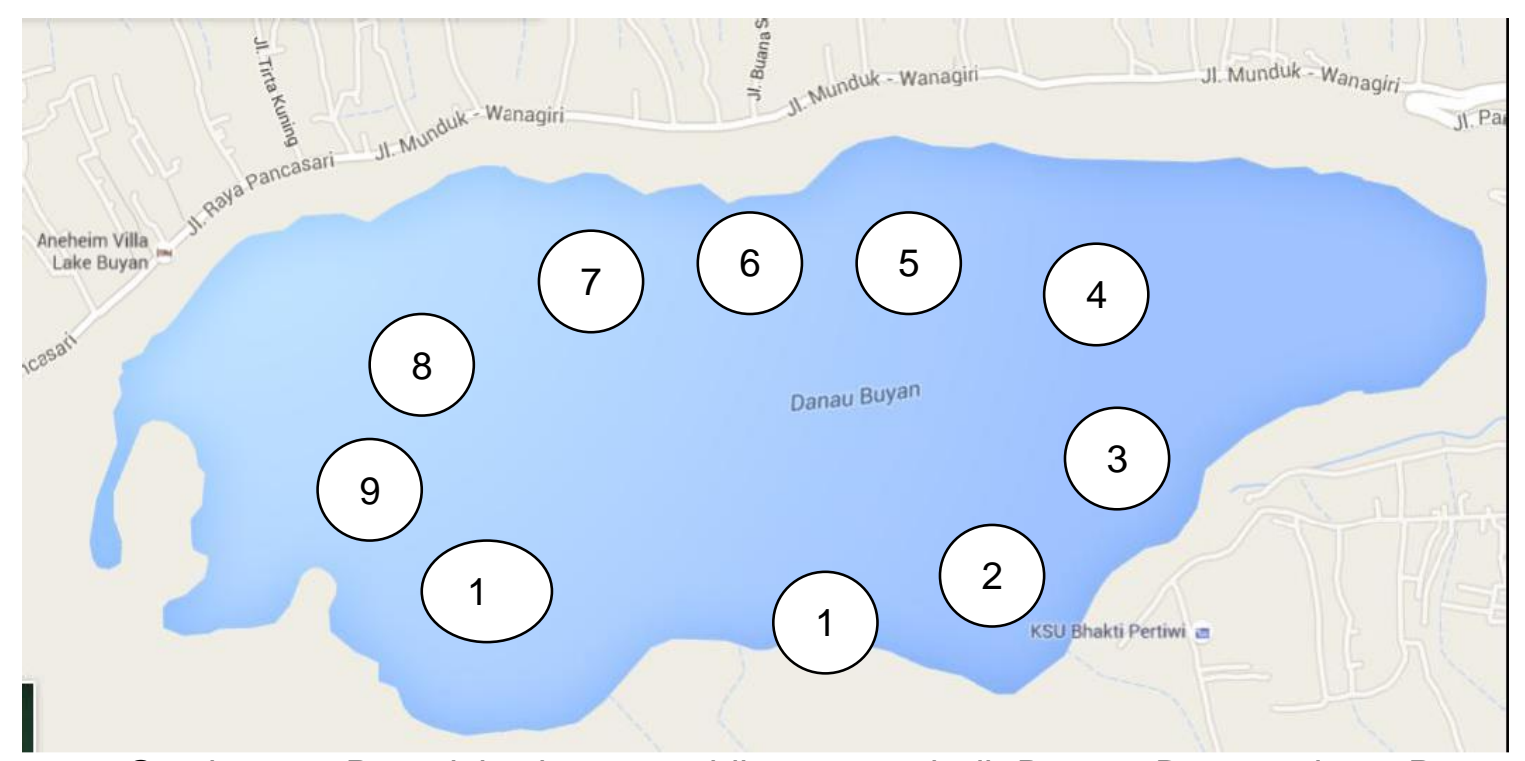

Gambar 1. Peta lokasi pengambilan sampel di Danau Buyan, desa Pancasari Sukasada, Buleleng

\section{d. Prosedur Pelaksanaan}

1. Pengukuran kulitas Fisik air Danau. Kualitas fisik Danau yang diukur antara lain: kecerahan, dan suhu air. Kecerahan diukur dengan piringan (modifikasi) yang dimasukkan ke dalam danau dan diukur kedalamannya, dan parameter fisik dan kimia air danau lainnya diukur dengan Water Quality Checker.

2. Penentuan kualitas air dengan metode Most Probable Number (MPM) (Fardiaz, 1993), dalam Lactosa Broth dengan seri tabung 333. Untuk uji kualitas ini terdiri dari 3 tahapan yaitu :

a. Presumptive test (uji pendugaan)

b. Confirmed test ( uji penegas)

c. Completed test (uji pelengkap)

3. Untuk mendeskripsikan ada tidaknya bakteri Escherichia coli dalam perairan ditumbuhkan pada media Eosin Methylene Blue Agar (EMBA).

\section{e. Metode Pengumpulan data}

Data parameter fisik dan kimia air danau Buyan dikumpulkan dari hasil pengukuran kedalaman penampakan secchi dish (modifikasi) dan hasil yang tertera pada alat Water Quality Checker. Data mikrobiologis air danau Buyan dikumpulkan dengan prosedur mikrobiologis menurut Cappuccino and Sherman (1987), dan Fardiaz (1993).

\section{f. Metode Analisis Data}

Data parameter fisik dianalisis secara deskriptif .Data mikrobiologis air danau Buyan yang dipeoleh antara lain :

1. Penentuan kualitas air secara MPN berdasarkan total coliform dianalisis dengan membandingkan nilai dari tabel MPN dan kualitas air menurut Permenkes

416/MENKES/PER/IX/1990, Peraturan Pemerintah RI nomor 82 tahun 2001, Keputusan Menteri Kesehatan Republik Indonesia Nomor 907/Menkes/SK/VII/2002 dan PERMENKES NO. 492/MENKES/Per/IV/2010, USDA (United States Department of Agriculture, 2014 / revisied ed) dan Sutton (2010).

2. Ada tidaknya bakteri $E$. coli dari hasil pengamatan koloni makroskopik dan mikroskopik dianalisis secara deskriptif

HASIL DAN PEMBAHASAN

1. Parameter fisik air danau Buyan 
Pengambilan data secara fisik, kimia dan mikrobiologis air danau Buyan yang dilakukan pada bulan September 2015 diperoleh data sebagai berikut pada Tabel 1 di bawah ini.

Tabel 1. Parameter Fisik Air Danau Buyan kecamatan Sukasada Buleleng-Bali

\begin{tabular}{ccccc}
\hline Stasiun & \multicolumn{4}{c}{ Parameter } \\
\cline { 2 - 5 } & $\mathrm{pH}$ & $\begin{array}{c}\text { Salinitas } \\
(P S U)\end{array}$ & $\begin{array}{c}\text { Kecerahan } \\
(\mathrm{cm})\end{array}$ & Suhu $\left({ }^{\circ} \mathrm{C}\right)$ \\
\hline 1 & 6,53 & 0,13 & 66 & 21,35 \\
2 & 7,58 & 0,13 & 153 & 21,17 \\
3 & 7,78 & 0,13 & 111 & 20,51 \\
4 & 7,59 & 0,13 & 152 & 20,78 \\
5 & 7,50 & 0,13 & 139,5 & 21,48 \\
6 & 7,60 & 0,13 & 170 & 22,10 \\
7 & 7.69 & 0,13 & 170 & 21,85 \\
8 & 7,80 & 0,13 & 175 & 22,26 \\
9 & 7,83 & 0,13 & 120 & 22,45 \\
10 & 7,90 & 0,13 & 119,5 & 22,50 \\
\hline \hline
\end{tabular}

Ket : PSU : Practical Salinity Units

2. Parameter kualitas air danau Buyan dengan metode MPN (Most Probable Number)
Nilai MPN yang didapatkan dalam penelitian ini pada 10 stasiun adalah seperti tertera pada Tabel 2 berikut.

Tabel 2. Nilai $M P N$ coliform di masing-masing stasiun penelitian menurut tabel MPN dari Fardiaz

(1993), USDA (United States Department of Agriculture, 2014 / revisied ed), Sutton

(2010), dan Cappuccino \& Sherman (1987) dengan waktu inkubasi 2 x 24 jam.

\begin{tabular}{|c|c|c|c|c|c|c|c|c|}
\hline \multirow[t]{3}{*}{ Stasiun } & \multicolumn{6}{|c|}{ Perubahan } & \multirow{3}{*}{$\begin{array}{c}\text { MPN } \\
\text { index } \\
\text { per } 100 \\
\text { mL }\end{array}$} & \multirow{3}{*}{$\begin{array}{l}95 \% \\
\text { confidence } \\
\text { range }\end{array}$} \\
\hline & \multicolumn{3}{|c|}{ Warna } & \multicolumn{3}{|c|}{ Terbentuk Gas } & & \\
\hline & $10 \mathrm{~mL}$ & $1 \mathrm{~mL}$ & $0,1 \mathrm{~mL}$ & $\begin{array}{r}10 \\
\mathrm{~mL}\end{array}$ & $\begin{array}{c}1 \\
\mathrm{~mL}\end{array}$ & $\begin{array}{l}0,1 \\
\mathrm{~mL}\end{array}$ & & \\
\hline 1 & $\begin{array}{l}\text { Perubahan } \\
\text { warna media } \\
\text { (3 tabung) }\end{array}$ & $\begin{array}{l}\text { Perubahan } \\
\text { warna media } \\
\text { (3 tabung) }\end{array}$ & $\begin{array}{l}\text { Perubahan } \\
\text { warna media ( } 3 \\
\text { tabung) }\end{array}$ & $3+$ & $3+$ & $3+$ & $>1100$ & $420-\infty$ \\
\hline 2 & $\begin{array}{l}\text { Perubahan } \\
\text { warna media } \\
\text { (3 tabung) }\end{array}$ & $\begin{array}{l}\text { Perubahan } \\
\text { warna media } \\
\text { ( } 3 \text { tabung) }\end{array}$ & $\begin{array}{l}\text { Perubahan } \\
\text { warna media ( } 3 \\
\text { tabung) }\end{array}$ & $2+$ & $1+$ & $1+$ & 20 & $4,5-42$ \\
\hline 3 & $\begin{array}{l}\text { Perubahan } \\
\text { warna media } \\
\text { (3 tabung) }\end{array}$ & $\begin{array}{l}\text { Perubahan } \\
\text { warna media } \\
\text { (3 tabung) }\end{array}$ & $\begin{array}{l}\text { Perubahan } \\
\text { warna media ( } 3 \\
\text { tabung) }\end{array}$ & $3+$ & $3+$ & $2+$ & 1100 & $180-4100$ \\
\hline 4 & $\begin{array}{l}\text { Perubahan } \\
\text { warna media } \\
\text { (3 tabung) }\end{array}$ & $\begin{array}{l}\text { Perubahan } \\
\text { warna media } \\
\text { ( } 3 \text { tabung) }\end{array}$ & $\begin{array}{l}\text { Perubahan } \\
\text { warna media ( } 3 \\
\text { tabung) }\end{array}$ & $3+$ & $3+$ & $3+$ & $>1100$ & $420-\infty$ \\
\hline 5 & $\begin{array}{l}\text { Perubahan } \\
\text { warna media } \\
\text { (3 tabung) }\end{array}$ & $\begin{array}{l}\text { Perubahan } \\
\text { warna media } \\
\text { ( } 2 \text { tabung) }\end{array}$ & $\begin{array}{l}\text { Perubahan } \\
\text { warna media ( } 3 \\
\text { tabung) }\end{array}$ & $3+$ & $2+$ & $3+$ & 290 & $90-1000$ \\
\hline 6 & $\begin{array}{l}\text { Perubahan } \\
\text { warna media } \\
\text { (3 tabung) }\end{array}$ & $\begin{array}{l}\text { Perubahan } \\
\text { warna media } \\
\text { (3 tabung) }\end{array}$ & $\begin{array}{l}\text { Perubahan } \\
\text { warna media ( } 3 \\
\text { tabung) }\end{array}$ & $3+$ & $2+$ & 0 & 93 & $18-420$ \\
\hline
\end{tabular}




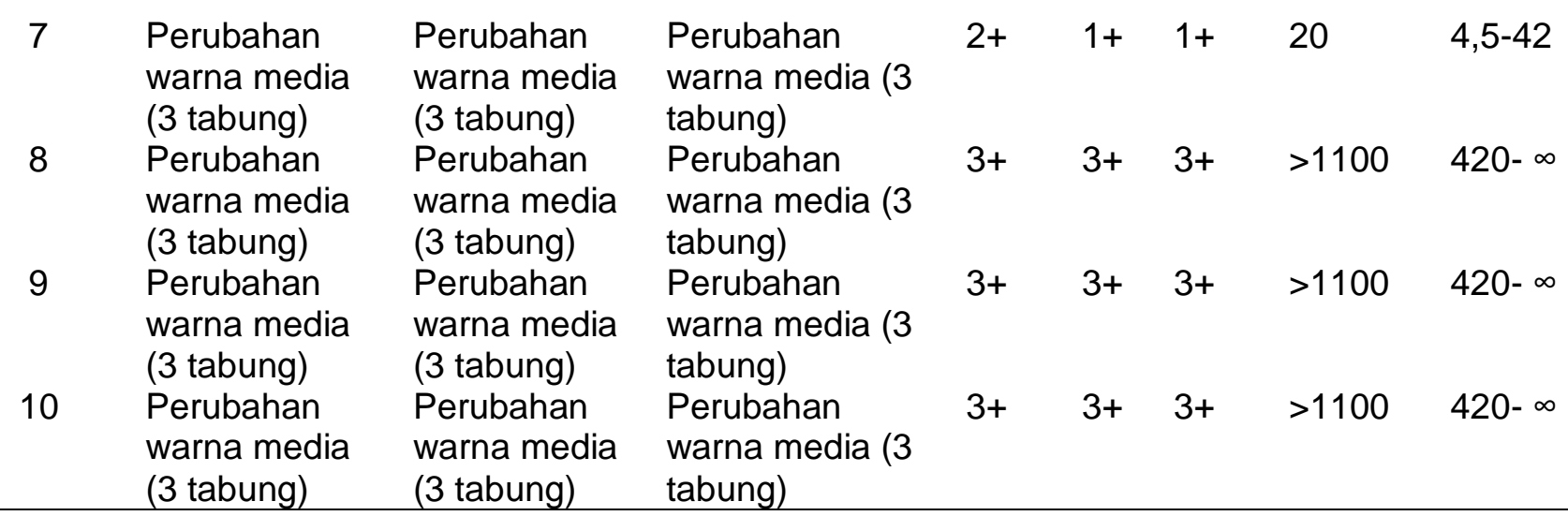

Hasil observasi pada media kaldu laktosa terjadi perubahan warna media dari kuning bening menjadi keruh dan terbentuknya gas pada tabung Durham (ditunjukkan tanda panah) dapat dilihat pada Gambar 2 di bawah ini.

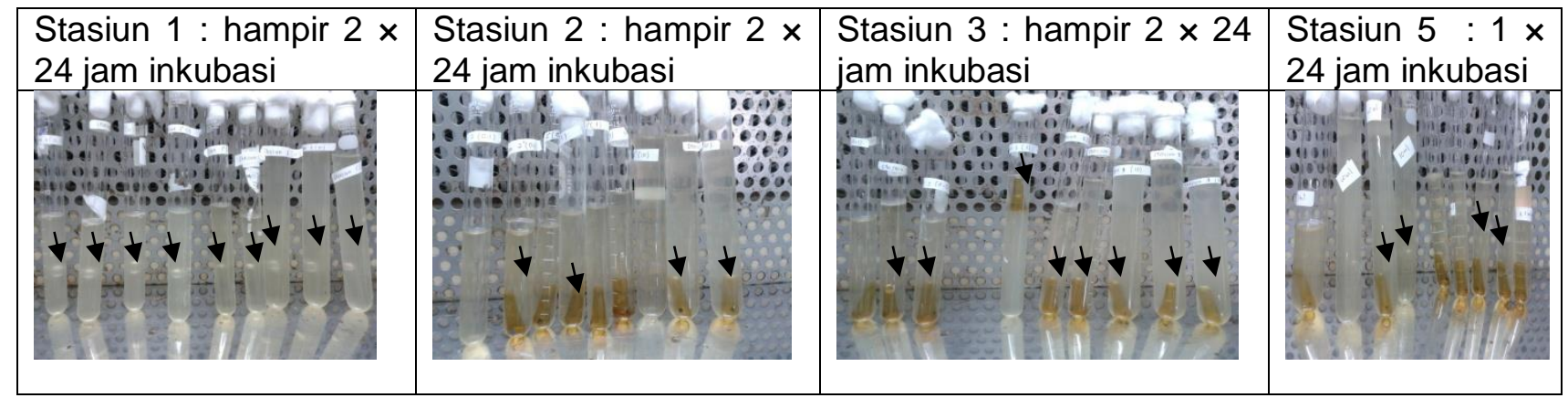

Gambar 2. Hasil observasi MPN pada inkubasi hampir $2 \times 24$ jam serial 333 tabung (uji penduga/presumtive test)

Setelah uji penduga dilanjutkan dengan uji penegasan dari tabung yang mengandung media kaldu laktosa yang terjadi perubahan warna dan terbentuk gas pada tabung Durham, dengan melakukan penanaman ke medium selektif untuk coliform yaitu EMBA (Eosin Methylene Blue Agar), dengan inkubasi $1 \times 24$ jam, dan juga uji penegas dan uji pelengkap didapatkan hasil seperti tercantum pada Tabel 3 di bawah ini.

Tabel 3. Uji penegas dan uji pelengkap MPN

\begin{tabular}{lll}
\hline Stasiun & Uji penegas (bakteri E.coli) & \multicolumn{1}{c}{ Uji pelengkap } \\
\hline 1 & Hijau Metalik (tanda panah) & Agar miring $(+)$ \\
& & LB terbentuk gas dan \\
& & perubahan warna $(+)$ \\
& & Agar miring $(+)$ \\
& Hijau Metalik (tanda panah) & perubahan warna $(+)$ \\
& & Agar miring $(+)$ \\
3 & Hijau Metalik (tidak didokumentasikan & LB terbentuk gas dan \\
& karena morfologi koloni sama dengan & perubahan warna $(+)$
\end{tabular}




\begin{tabular}{|c|c|c|}
\hline 4 & $\begin{array}{l}\text { Hijau Metalik (tidak didokumentasikan } \\
\text { karena morfologi koloni sama dengan } \\
\text { stasiun yang didokumentasikan) }\end{array}$ & $\begin{array}{l}\text { Agar miring }(+) \\
L B \text { terbentuk gas dan } \\
\text { perubahan warna }(+)\end{array}$ \\
\hline 5 & Hijau Metalik (tanda panah) & $\begin{array}{l}\text { Agar miring }(+) \\
L B \text { rbentuk tgas dan } \\
\text { perubahan warna }(+)\end{array}$ \\
\hline 6 & Hijau Metalik (tanda panah) & $\begin{array}{l}\text { Agar miring }(+) \\
L B \text { terbentuk gas dan } \\
\text { perubahan warna }(+)\end{array}$ \\
\hline 7 & Hijau Metalik (tanda panah) & $\begin{array}{l}\text { Agar miring }(+) \\
L B \text { terbentuk gas dan } \\
\text { perubahan warna }(+)\end{array}$ \\
\hline 8 & $\begin{array}{l}\text { Hijau Metalik (tidak didokumentasikan } \\
\text { karena morfologi koloni sama dengan } \\
\text { stasiun yang didokumentasikan) }\end{array}$ & $\begin{array}{l}\text { Agar miring }(+) \\
L B \text { terbentuk gas dan } \\
\text { perubahan warna }(+)\end{array}$ \\
\hline 9 & $\begin{array}{l}\text { Hijau Metalik (tidak didokumentasikan } \\
\text { karena morfologi koloni sama dengan } \\
\text { stasiun yang didokumentasikan) }\end{array}$ & $\begin{array}{l}\text { Agar miring }(+) \\
L B \text { terbentuk gas dan } \\
\text { perubahan warna }(+)\end{array}$ \\
\hline 10 & $\begin{array}{l}\text { Hijau Metalik (tidak didokumentasikan } \\
\text { karena morfologi koloni sama dengan } \\
\text { stasiun yang didokumentasikan) }\end{array}$ & $\begin{array}{l}\text { Agar miring }(+) \\
L B \text { terbentuk gas dan } \\
\text { perubahan warna }(+)\end{array}$ \\
\hline
\end{tabular}

Hasil inkubasi bakteri yang telah dibiakkan di media Laktosa Broth pada Tabel 3, dapat dilihat pada Gambar 3.
Hasil observasi uji pelengkap (completed test) dari Tabel 3 di atas selanjutnya dilakukan pewarnaan Gram, dengan hasil tertera seperti Gambar 4.

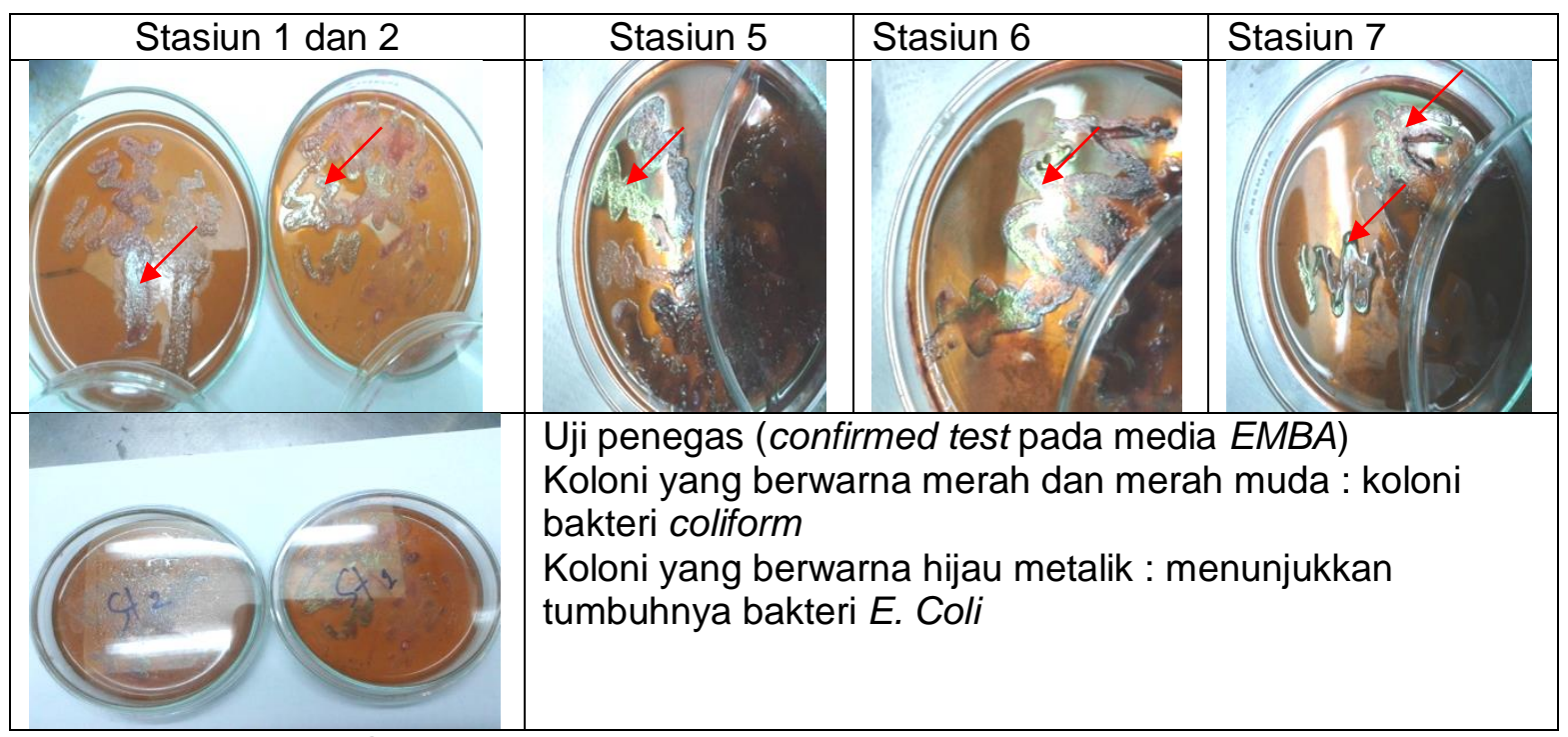

Gambar 3. Hasil confirmed test pada media EMBA 


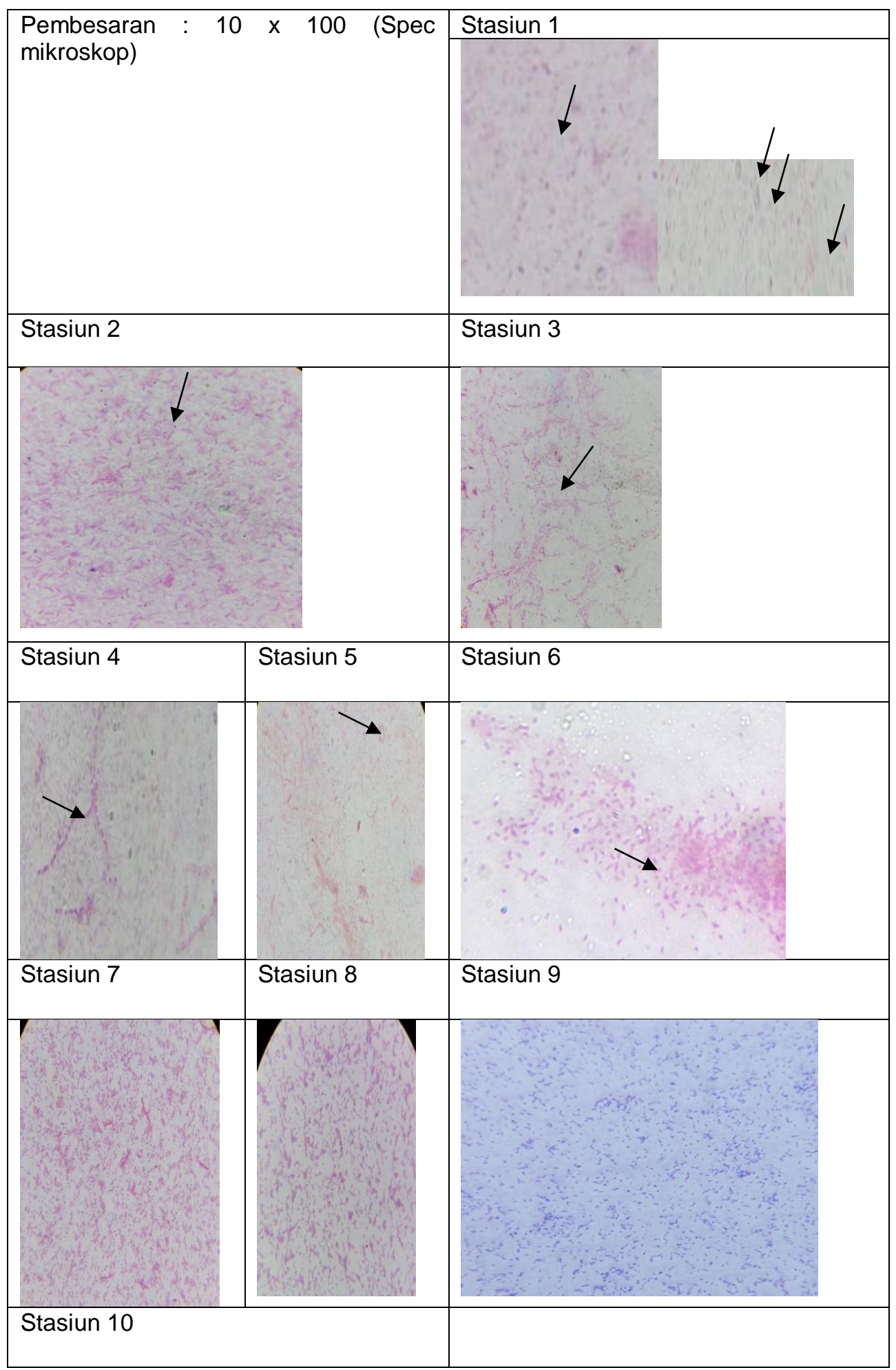




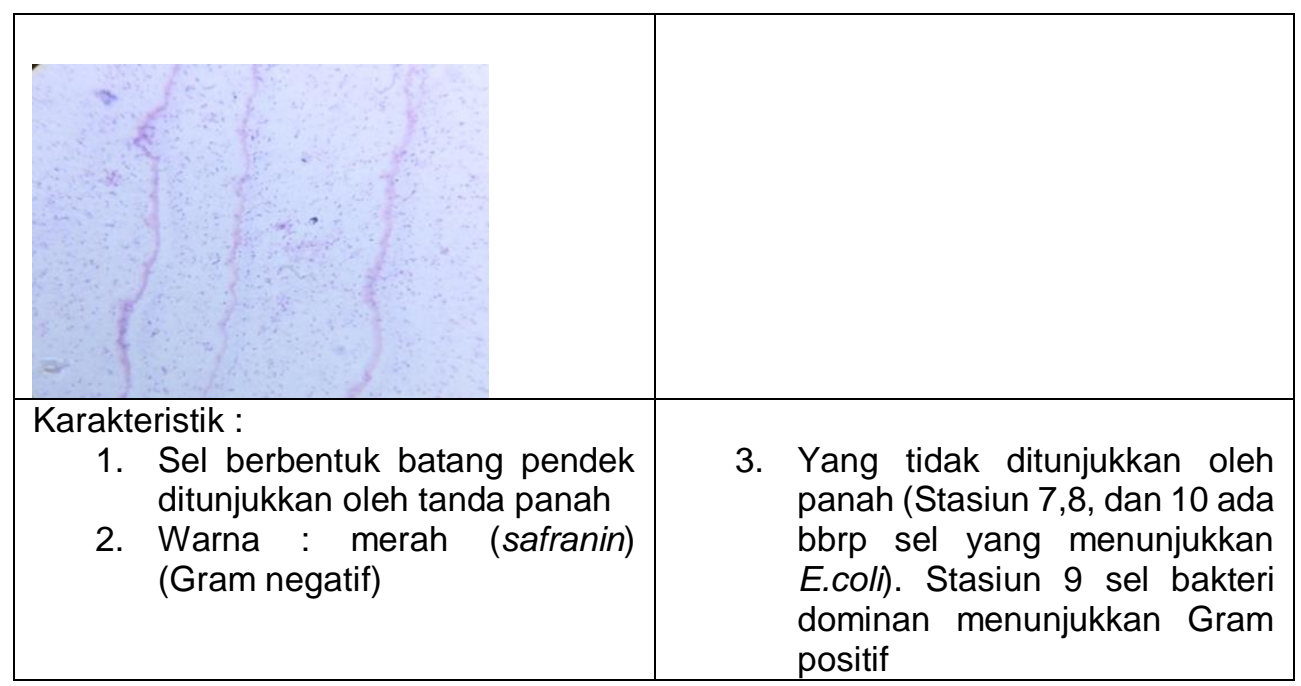

Gambar 4. Hasil pewarnaan gram bakteri pada masing-masing stasiun di Danau Buyan

Dari Tabel 3 menunjukkan nilai MPN danau Buyan mengindikasikan bahwa air danau Buyan kecamatan Sukasada Buleleng Bali tidak memenuhi persyaratan sebagai air minum seperti yang tertuang dalam Permenkes 416/MENKES/PER/IX/1990, PERMENKES NO.907/MENKES/SK/VII/2002 dan PERMENKES

NO.

492/MENKES/Per/IV/2010 tentang jumLah bakteri E.coli dan total coliform per $100 \mathrm{~mL}$ sampel adalah 0 untuk air minum. Sedangkan menurut Peraturan Pemerintah Republik Indonesia Nomor 82 Tahun 2001 tentang Pengelolaan Kualitas Air dan Pengendalian Pencemaran Air untuk ke-10 stasiun mempunyai nilai indeks MPN berbeda-beda dan mempunyai kualitas kelas air yang berbeda. Pengelolaan kualitas air adalah upaya pemeliharaan air sehingga tercapai kualitas air yang diinginkan sesuai peruntukkannya menjamin agar kualitas air tetap dalam kondisi alamiahnya. Untuk stasiun 2,5,6,7 termasuk kelas 1 karena nilai coliform MPN secara kualitatif masih di bawah ambang batas total coliform yang diperbolehkan yaitu 1000 per $100 \mathrm{~mL}$ air. Untuk stasiun 3 tergolong air kualitas kelas 2 yaitu masih di bawah 5000 per $100 \mathrm{~mL}$ air. Sedangkan stasiun nomor 1,4,8,9 dan 10 kemungkinan tergolong kualitas air kelas 2,3 atau 4 karena nilai MPN/100 mL lebih dari 1100 dengan range coliform 420- $\infty$ (USDA,
2014). Untuk jumLah secara terperinci tidak dilakukan, karena tidak dilakukan pengenceran berseri yang lebih kecil. Penelitian yang dilakukan oleh Widiyanti \& Ristiati (2004) ketiga depo air minum isi ulang di kota Singaraja kualitas airnya berdasarkan uji pendugaan (presumtive test) memenuhi syarat mutu Permenkes No 416/Menkes/Per/IX/1990.

Bakteri golongan Coli (Coliform bakteri) merupakan bakteri indikator dari pencemaran air oleh bakteri patogen (Slamet, 2000). Hasil dari pertumbuhan bakteri pada media EMBA dan pewarnaan Gram pada media kaldu laktosa, menunjukkan menunjukkan bahwa bakteri diidentifikasi dari air danau Buyan. Bakteri coli dibedakan menjadi 2 yaitu coli umum dan fecal coli (Suriawiria, 2008). Sedangkan menurut Fardiaz (1993) Bakteri koliform dapat dibedakan menjadi 2 grup yaitu : (1) koliform fekal misalnya Escherichia coli dan (2) koliform nonfekal misalnya Enterobacter aerogenes. Escherichia coli merupakan bakteri yang berasal dari kotoran hewan atau manusia, sedangkan Enterobacter aerogenes biasanya ditemukan pada hewan atau tanam-tanaman yang telah mati (Fardiaz, 1993 ).

Bakteri golongan Coli (Coliform bakteri) merupakan bakteri indikator dari pencemaran air oleh bakteri patogen (Slamet, 2000). Bakteri golongan coli (coliform) antara lain bakteri E.coli 
merupakan flora normal usus/kolon. E.coli menyebabkan penyakit diare yang diklasifikasikan berdasarkan ciri khas dan sifat virulensinya, dan setiap kelompok mempunyai mekanisme yang berbeda dalam menimbulkan penyakit. E.coli Enteropatogenik (EPEC/Enteropatogenic E.coli) adalah penyebab penting diare pada bayi, khususnya di negara berkembang. EPEC melekat pada permukaan sel mukosa usus kecil. Kadang-kadang EPEC masuk ke dalam sel mukosa. EPEC menyebabkan diare cair yang biasanya sembuh sendiri dan dapat juga menjadi diare kronik. Pemberian antibiotik untuk diare kronik diobati dengan pemberian antibiotik. Diare EPEC dapat diidentifikasi melalui antigen $\mathrm{O}$ dan antigen flagela $(\mathrm{H})$ (Brooks et al, 1995).

$$
\text { E. coli Enterotosigenik }
$$

(ETEC/Enterotoxigenic E.coli) adalah penyebab "diare wisatawan" dan sangat penting menyebabkan diare pada bayi di negara berkembang. ETEC melekat pada sel epitel usus kecil. Beberapa strain ETEC menghasilkan labil toksin (LT). Subunit B nya menempel pada gangliosida Gm1 di brush border sel epitel usus kecil dan memudahkan masuknya protein sub unit $A$ ke dalam sel dan protein ini mengaktifkan adenilin siklase. Ini akan menyebabkan peningkatan konsentrasi siklik adenosin monofosfat (cAMP) setempat, yang menimbulkan hipersekresi air dan klorida yang terus menerus dan lama, disertai penghambatan reabsorpsi natrium. Lumen usus teregang oleh cairan, dan mengakibatkan hipermotilitas serta diare, ini berlangsung selama bberapa hari. Beberapa strain ETEC menghasilkan stabil toksin (STa dan STb). Banyak strain positif STa juga menghasilkan LT. Strain dengan kedua toksin ini (STa dan LT) menimbulkan diare yang berat.

\section{E.coli Enterohemoragik (EHEC/Enterohemorrhagic E.coli)} menghasilkan verotoksin, dinamai sesuai efek sitotoksisnya pada sel Vero (sel ginjal dari monyet hijau Afrika). Terdapat sedikitnya 2 bentuk antigenik dan toksin. EHEC berhubungan dengan kolitis hemoragik yaitu diare berat dan dengan sindroma uremia hemolitik (penyakit akibat gagal ginjal akut), anemia hemolitik mikroangiopatik dan trombositopenia. Verotoksin memiliki banyak sifat yang mirip dengan toksin Shiga yang dihasilkan oleh beberapa strain Shigella dysentriae tipe1, namun Verotoksin dan toksin Shiga berbeda secara antigenik dan genetik.

$$
\text { E.coli Enteroinvasif }
$$

(EIEC/Enteroinvasive E.coli) menimbulkan penyakit yang sangat mirip dengan shigelosis. Penyakit paling sering terjadi pada anak-anak dan para wisatawan yang menuju ke negara tersebut. EIEC menimbulkan penyakit melalui invasinya ke sel epitel mukosa usus.

E.coli Enteroagregatif ( $E A E C /$ Enteroagregative E.coli) menyebabkan diare akut dan kronik pada masyarakat di negara berkembang. Sangat sedikit yang diketahui mengenai faktor virulensi EAEC dan epidemiologinya. ( Brooks, et al, 1995).

Menurut Permenkes RI No. 416/MENKES/PER/IX/1990, bakteri coliform yang memenuhi syarat untuk air bersih bukan perpipaan adalah $<50$ MPN. Secara umum, air Danau Buyan tidak memenuhi persyaratan sebagai air bersih menurut $\mathrm{Rl}$ No. 416/MENKES/PER/IX/1990 karena sebagian besar nilai MPN melebihi dari 50 (stasiun 1, 3,4,5,6,8,9,10)

Berdasarkan lokasi pengambilan sampel air, stasiun 1 merupakan titik pengambilan sampel yang berada paling dekat dengan daratan (lahan pemukiman dan perkebunan). Jarak pemukiman penduduk dan kamar mandi umum dengan danau sangat dekat yaitu sekitar 20 sampai 50 meter, sedangkan jarak terdekat antara danau dengan lahan perkebunan sekitar 15 meter. Menurut Chandra (2009), sumber air harus berjarak minimal 15 meter dan terletak lebih tinggi dari sumber pencemaran seperti kakus, kandang ternak, tempat sampah, dan sebagainya. Sedangkan keadaan di kawasan Danau Buyan adalah toilet umum dan perumahan warga terletak lebih tinggi dari danau. Sehingga bahan-bahan pencemar sangat mungkin merembes menuju danau walaupun jarak danau dengan sumber pencemar sudah di atas 
batas minimal. Selain itu pada Stasiun 1 banyak ditemukan timbunan sampah organik maupun anorganik. Stasiun 2 berada dekat dengan Stasiun 1, sehingga kemungkinan sampah dan bahan pencemar yang ditemukan pada Stasiun 1 terbawa ke Stasiun 2. Stasiun 3 letaknya dekat dengan stasiun 2 dan berada di lokasi keramba ikan. Stasiun 4 lokasinya juga merupakan lokasi keramba ikan. Lokasi 5 letaknya dekat dengan tebing. Stasiun 6 dan 7 merupakan lokasi pengambilan sampel yang berada di pinggir danau dekat tebing. Stasiun 8,9 dan 10 berada lebih jauh dengan pemukiman penduduk, tetapi mendekati lokasi perkemahan.

Jarak pemukiman penduduk dan kamar mandi umum dengan danau sangat dekat yaitu sekitar 20 sampai 50 meter, sedangkan jarak terdekat antara danau dengan lahan perkebunan sekitar 15 meter. Menurut Chandra (2009), sumber air harus berjarak minimal 15 meter dan terletak lebih tinggi dari sumber pencemaran seperti kakus, kandang ternak, tempat sampah, dan sebagainya. Sedangkan keadaan di kawasan Danau Buyan adalah toilet umum dan perumahan warga terletak lebih tinggi dari danau. Sehingga bahan-bahan pencemar sangat mungkin merembes menuju danau walaupun jarak danau dengan sumber pencemar sudah di atas batas minimal.

\section{Simpulan}

Adapun beberapa simpulan yang dapat ditarik dari hasil penelitian ini antara lain: parameter fisik air danau Buyan yang terukur pada saat penelitian : $\mathrm{pH}$ terendah tidak memenuhi baku mutu air untuk konsumsi, kecerahan air tidak memenuhi baku mutu air. Sedangkan parameter lainnya seperti $\mathrm{pH}$ tertinggi, salinitas dan suhu memenuhi baku mutu air. JumLah total bakteri coliform pada air Danau Buyan berdasarkan metode Most Probable Number berkisar antara $20->1100$.

\section{Saran}

Berdasarkan hasil penelitian yang diperoleh dapat diberikan beberapa saran sebagai berikut: masyarakat sekitar danau Buyan hendaknya tidak membangun rumah terlalu dekat dengan danau, dan ikut menjaga ekosistem danau. Masyarakat hendaknya tidak menggunakan air danau untuk dikonsumsi secara langsung atau jika ingin menggunakannya sebaiknya dilakukan pengolahan terlebih dahulu sesuai dengan standar kesehatan yang telah ditetapkan.

\section{DAFTAR PUSTAKA}

Athena, Sukar, Hendro M., D. Anwar M. dan Haryono. 2004. Kandungan Bakteri Total Coli dan Escherichia coli/Fecal coli Air Minum Dari Depot Air Minum Isi Ulang di Jakarta, Tanggerang, dan Bekasi. Balai Penelitian Kesehatan. 3 (4) :135-143

Brooks, G,F., Butel, J.S., Ornston, L, N. 1995. Jawetz, Melnick \& Adelberg Mikrobiologi Kedokteran. Edisi 20 Alih bahasa : Edi Nugroho dan R.F Maulany . Jakarta : EGC

Cappuccino, J. G. and Sherman, N. 1987. Microbiology A Laboratory Manual. Menlo Park, California : The Benjamin/Cummings Pub.Co,Inc

Chandra, B. 2009. Ilmu KedokteranPencegahan \& Komunitas. Jakarta : Penerbit Buku Kedokteran EGC.

Effendi, H. 2007. Telaah Kualitas Air Bagi Pengelolaan Sumber Daya dan Lingkungan Perairan. Yogyakarta: Kanisius.

Fardiaz, S. 1993. Analisis Mikrobiologi Pangan. Jakarta Utara: PT Raja Grafindo Persada.

Kementerian Kesehatan Republik Indonesia. 2010. Peraturan Menteri Kesehatan Republik Indonesia No. 492 Tahun 2010 tentang Persyaratan Kualitas Air Minum

Meadows, P.S and Campbell, J.I. 1988. An Introduction to Marine Science. New York : John Wiley and Sons.

Menteri Kesehatan RI. 1990. Syarat-syarat dan Pengawasan Kualitas Air. Peraturan Menteri Kesehatan 
Republik Indonesia Nomor 416/MENKES/PER/IX/1990.

Menteri Kesehatan. 2002. Peraturan Pemerintah RI nomor 82 tahun 2001, Keputusan Menteri Kesehatan Republik Indonesia Nomor 907/Menkes/SK/VII/2002

Slamet, J.S. 2000. Kesehatan Lingkungan. Yogyakarta : UGM Press

Suriawiria U. 2008. Mikrobiologi Air. Bandung: Alumni

Sutton, S. 2010. Microbiology Topics. The Most Probable Number Method And Its Uses in Enumeration, Qualification, and Validation. J. Of Validation Technology Summer. 16 (3)

United States Department of Agriculture (USDA). 2014. Revisied ed. Laboratory Guide Book. Most Probable Number Procedure and Tables. United States Department of Agriculture. Food Safety and Inspection Service. Office of Public Health Science. Laboratory QA Staff 950 Collage Station Road Athens, GA 30605

Widiyanti, N.L dan Ristiati, N.P. 2004. Analisis Kualitatif Bakteri Koliform pada Depot air Minum Isi Ulang di Kota Singaraja Bali. Jurnal. Ekologi. Kes : 3 (1) : 64-73 